\title{
Differential metallothionein, reduced glutathione and metal levels in Perna perna mussels in two environmentally impacted tropical bays in southeastern Brazil
}

\author{
Raquel T. Lavradas ${ }^{a}$, Rafael C.C. Rocha ${ }^{a}$, Isabella C.A.C. Bordon ${ }^{b}$, Tatiana D. Saint'Pierre ${ }^{a}$, \\ José M. Godoy ${ }^{a}$, Rachel A. Hauser-Davis ${ }^{\mathrm{c}, *}$ \\ ${ }^{a}$ Pontifical Catholic University of Rio de Janeiro (PUC-Rio), Chemistry Department, Rua Marquês de São Vicente, 225, Gávea, CEP 22453-900 Rio de Janeiro, \\ RJ, Brazil \\ ${ }^{\mathrm{b}}$ São Paulo State University (UNESP), Campus do Litoral Paulista, Praça Infante Dom Henrique s/nº, Parque Bitaru, CEP $11330-900$ São Vicente, SP, Brazil \\ ${ }^{\text {c }}$ Federal University of the State of Rio de Janeiro - UNIRIO, Neotropical Biodiversity Post-Graduate Program, Av. Pasteur, 458, Urca, CEP 22290-240 Rio de \\ Janeiro, RJ, Brazil
}

\section{A R T I C L E I N F O}

\section{Article history:}

Received 18 January 2016

Received in revised form

5 March 2016

Accepted 7 March 2016

Available online 17 March 2016

\section{Keywords:}

Metals

Metallothionein

Oxidative stress

Mussels

Risk assessment

Tropical Bays

\begin{abstract}
A B S T R A C T
Mussel farming is an important economic activity in Brazil, and these organisms are consumed by the majority of the population in most coastal zones in the country. However, despite the increasing pollution of aquatic ecosystems in Brazil, little is known about the biochemical activity in mussels in response to metal exposure. In this context, the aim of the present study was to investigate metal and metalloid exposure effects in Perna perna mussels, by determining metal levels, the induction of metallothionein (MT) synthesis, and oxidative stress, in the form of reduced glutathione (GSH) in 3 contaminated areas from the Guanabara Bay in comparison to a reference site, Ilha Grande Bay, both in summer and winter. Metal and metalloid concentrations were also compared to Brazilian and international guidelines, to verify potential health risks to human consumers. Mussels from all sampling sites were shown to be improper for human consumption due to metal contamination, including Ilha Grande Bay, which has previously been considered a reference site. Several statistically significant correlations and seasonal differences were observed between MT, GSH and metals and metalloids in both analyzed tissues. A Discriminant Canonical Analysis indicated that the digestive gland is a better bioindicator for environmental contamination by metals and metalloids in this species and offers further proof that MT variations observed are due to metal exposure and not oxidative stress, since GSH influence for both muscle tissue and the digestive glands was non-significant in this analysis. These results show that $P$. perna mussels are an adequate sentinel species for metal contamination with significant effects on oxidative stress and metal exposure biomarkers. To the best of our knowledge, this is the first study to report metals, metalloids, MT and GSH levels in the muscle tissue of this species.
\end{abstract}

(c) 2016 Elsevier Inc. All rights reserved.

\section{Introduction}

The contamination of the aquatic environment by metals and metalloid species has become a global problem in the last decades. Among environmental pollutants, these contaminants are of particular concern due to their potential toxic effects and their ability to bioaccumulate in aquatic ecosystems (MacFarlane and Burchett, 2000; Miller et al., 2002). Often, the criterion used to classify a substance as harmful or not is the death (or not) of an organism. This, however, is a very extreme option, where no preventive

\footnotetext{
* Corresponding author.

E-mail address: rachel.hauser.davis@gmail.com (R.A. Hauser-Davis).
}

action can be taken. Therefore, it is more accurate to measure the sublethal effects of pollutants in the biota, which arise long before death. This is conducted through the use of biomarkers (Moore et al., 2004; Van Der Oost et al., 2003; Viarengo et al., 2007).

Certain biomarkers are useful in indicating oxidative stress, which takes place in response to exposure to metal and metalloid species. Oxidative stress occurs when cellular defense mechanisms are unable to act on free radicals or on their deleterious effects. The glutathione system is one of the first lines of defense against oxidative stress, which includes reduced glutathione (GSH), in addition to antioxidant enzymes such as catalase and superoxide dismutase, being of vital importance in aquatic ecotoxicology analyses to understand and unravel the mechanisms of action of environmental contaminants. The second line of defense against 
oxidative stress is composed of metallothioneins (MT). These metalloproteins, due to their abundant cysteine residues, are also known for their protective free radical scavenging activity, playing an active role in the capture of harmful oxidant radical species (Kumari et al., 1998). This, though, has been mostly reported for mammals regarding MT in the central nervous system, while studies in aquatic organisms such as fish as fish and mussels are still scarce. Some studies in this regard with mussels have demonstrated that MT is induced in response to factors promoting oxidative stress (Viarengo et al., 1999). However, the main role investigated regarding MT is the fact that they have a high affinity for metal ions and function as both mediators of physiological metal homeostasis and the detoxification of essential and nonessential metals. The induction of this metalloprotein is, in fact, one of the main biomarkers established in biomonitoring programs in the European community (Garrigues et al., 2002; Ramos et al., 2000; Viarengo et al., 1997).

Despite the increasing pollution of aquatic ecosystems in Brazil, little is known about the biochemical response of certain organisms, such as mussels, in response to metal exposure. The Guanabara Bay is considered heavily contaminated by these pollutants (Almeida, 2003), while Ilha Grande Bay is a reasonably preserved area, with no history of environmental contamination by metals and metalloid species, and is, therefore, regularly used as a reference area for environmental monitoring studies (Cardoso et al., 2001; Junior et al., 2002; Lavradas et al., 2014).

In this context, the aim of the present study was to investigate metal and metalloid exposure in Perna perna mussels, by determining metal levels and the induction of metallothionein synthesis and oxidative stress, in the form of GSH, comparing these biochemical responses throughout the different sampling sites in two seasons, summer and winter. Among the different species of mussel, $P$. perna is the most cultivated along the Brazilian coast, since it reaches larger sizes, grows relatively fast, has a high production rate, is nutritious and easily collected (Baraj et al., 2003a). In addition, metal and metalloid concentrations were compared to Brazilian and international guidelines, in order to verify if the consumption of this species can bring potential health risks to human consumers due to metal bioaccumulation.

\section{Methodology}

\subsection{Study area}

The Guanabara Bay, located in the state of Rio de Janeiro, latitude $22^{\circ} 24^{\prime} \mathrm{S}-22^{\circ} 57^{\prime} \mathrm{S}$ and longitude $43^{\circ} 33^{\prime} \mathrm{W}-43^{\circ} 19^{\prime} \mathrm{W}$ (Kjerfve et al., 1997), is one of the most important coastal bays in Brazil (Amador, 1997). Several sources of pollution are present in this area, such as surrounding industries (over 6000) of which 52 are responsible for $80 \%$ of the industrial pollution of the bay, including the Duque de Caxias refinery (REDUC), marine oil terminals (16); commercial ports (2); advanced fuel stations (2000) and shipyards (32). In addition, domestic sewage, waste leakage and the occupation of public land bordering the rivers and hillsides increase the daily pollutant loads discharged into the bay (Almeida, 2003).

Ilha Grande Bay, located on the southern coast of the state of Rio de Janeiro, latitude $22^{\circ} 50^{\prime} \mathrm{S}-20^{\prime} \mathrm{S}$ and $23^{\circ} 45^{\prime} \mathrm{W}$ longitude $44^{\circ}-$ $44^{\circ} 00^{\prime} \mathrm{W}$ (Creed et al., 2007), is a very rugged bay, composed of several small bays inside, and dotted with many islands that decrease the hydrodynamics of the area. It is an important tourist region for Rio de Janeiro and is considered one of the most important areas of this state in terms of fishing productivity (Bizerril and Costa, 2001; Kehrig et al., 1998). This area has been repeatedly considered a reference area due to low environmental metal levels (Cardoso et al., 2001; Lacerda et al., 1989; Lavradas et al., 2014).

\subsection{Mussel sampling}

P. perna mussels were sampled from different beaches belonging to the Guanabara Bay (GB, Diabo Beach, Urca Beach and Vermelha Beach - DB, UB and VB) and from Ilha Grande Bay (IG) during the summer and winter seasons of the same year. Individuals were measured (shell length, width and height) and grouped according to size range, totalling four composite samples, each containing 10 individuals. The digestive glands and adductor muscle tissue were removed and freeze-dried for $48 \mathrm{~h}$ (Liotop 101, Liobrás, São Paulo, Brazil).

\subsection{Metal and metalloid determinations}

The freeze-dried samples were decomposed in an acid medium with subdistilled nitric acid at $100{ }^{\circ} \mathrm{C}$ for $5 \mathrm{~h}$. After cooling, the volumes were adjusted with ultra pure water (resistivity $>18 \mathrm{M} \Omega \mathrm{cm}$ ) for subsequent analysis by inductively coupled plasma mass spectrometry (ICP-MS). The metals and metalloids were determined on an Elan DRC II (Perkin-Elmer Sciex, Norwalk, CT, USA) spectrometer without the use of a reaction cell. Sample introduction was conducted using a Meinhard nebulizer with cyclonic chamber and twister. The following isotopes were monitored: ${ }^{60} \mathrm{Ni},{ }^{65} \mathrm{Cu},{ }^{66} \mathrm{Zn},{ }^{75} \mathrm{As},{ }^{82} \mathrm{Se},{ }^{114} \mathrm{Cd},{ }^{202} \mathrm{Hg},{ }^{208} \mathrm{~Pb}$. Quality control was performed by a strict blank control, the analyses of replicates and certified reference materials. Accuracy was assessed through the analysis of certified material DORM-4 (National Research Council, Canada), composed of dog-fish muscle impregnated with known amounts of metals and trace-elements (Ni: $1.36 \pm 0.22 \mu \mathrm{g} \mathrm{g}^{-1}$; Cu: $15.9 \pm 0.9 \mu \mathrm{g} \mathrm{g}^{-1} ; \mathrm{Zn}: 52.2 \pm 3.2 \mu \mathrm{g} \mathrm{g}^{-1}$; As: $\quad 6.80 \pm 0.64 \mu^{-1} \mathrm{~g}^{-1} ; \quad$ Se: $\quad 3.56 \pm 0.34 \mu \mathrm{g} \mathrm{g}^{-1}$; $\quad$ Cd: $\left.0.306 \pm 0.015 \mu \mathrm{g} \mathrm{g}^{-1} ; \mathrm{Pb}: 0.416 \pm 0.053 \mu \mathrm{g} \mathrm{g}^{-1}\right)$. No statistically significant difference was observed between certified DORM- 4 and observed values (Ni: $1.28 \pm 0.15 \mu \mathrm{g} \mathrm{g}^{-1}$; Cu: $15.6 \pm 0.5 \mu \mathrm{g} \mathrm{g}^{-1}$; $\mathrm{Zn}$ : $51.5 \pm 1.7 \mu \mathrm{g} \mathrm{g}^{-1}$; As: $7.03 \pm 0.20 \mu \mathrm{g} \mathrm{g}^{-1}$; Se: $3.63 \pm 0.25 \mu \mathrm{g} \mathrm{g}^{-1}$; $\left.\mathrm{Cd}: \quad 0.310 \pm 0.012 \mu \mathrm{g} \mathrm{g}^{-1} ; \quad \mathrm{Pb}: \quad 0.410 \pm 0.05 \mu \mathrm{g} \mathrm{g}^{-1}\right)$. Recoveries ranged from $94 \%$ to $103 \%$ and were considered appropriate for the present study.

\subsection{GSH extraction and determination}

GSH extraction was performed according to Beutler (1975), with modifications introduced by Wilhelm-Filho et al. (2005). Briefly, approximately $25 \mathrm{mg}$ of each sample was homogenized in $350 \mu \mathrm{L}$ of $0.1 \mathrm{~mol} \mathrm{~L}^{-1} \mathrm{pH} 7.0$ sodium phosphate buffer containing sucrose $0.25 \mathrm{~mol} \mathrm{~L}^{-1}$ in an inert atmosphere (nitrogen $99.9 \%$ ). The samples were then centrifuged at $11.000 \times \mathrm{g}$ in a Mikro 220R centrifuge (Hettich, Alemanha) for $30 \mathrm{~min}$ at $4{ }^{\circ} \mathrm{C}$. The supernatants were removed, transferred to sterile microtubes and subsequently treated with $0.1 \mathrm{~mol} \mathrm{~L}^{-1}$ DTNB in $\mathrm{pH} 8.0$ sodium phosphate buffer at a 1:1 ratio. After a 15 min incubation in the dark the sample absorbances were determined at $412 \mathrm{~nm}$ on a UV-vis spectrophotometer (Lambda 35, Perkin Elmer). GSH concentrations were estimated using an analytical curve plotted with GSH as the external standard (Monteiro, 2006).

\subsection{MT extraction and determination}

MT was extracted according to the thermal procedure described by Erk and collaborators, using tris-2-carboxyethyl-phosphine (TCEP) as the reducing agent (Sigma-Aldrich, São Paulo, Brazil) (Erk et al., 2002; Getz et al., 1999; Tenório-Daussat et al., 2014). Briefly, the samples were homogenized in sterile polypropylene microtubes at a 1:20 ration in a buffer solution containing Tris- $\mathrm{HCl}, 20 \mathrm{mmol} \mathrm{L}^{-1} \mathrm{pH}$ 8.6, phenyl methyl sulfonyl fluoride $0.5 \mathrm{mmol} \mathrm{L}^{-1}$ and $0.01 \%$ TCEP. The samples were then 
centrifuged in a refrigerated microtube centrifuge (Mikro $220 \mathrm{R}$, Hettich, Germany) at $20,000 \times \mathrm{g}$ for $60 \mathrm{~min}$ at $4{ }^{\circ} \mathrm{C}$ and the supernatants were carefully removed and transferred to other sterile microtubes. The supernatants were subsequently heated at $70{ }^{\circ} \mathrm{C}$ for $10 \mathrm{~min}$ in a thermostatic water bath (Kacil, São Paulo, Brazil) and a new centrifugation at 20,000 $\times g$ was performed for $30 \mathrm{~min}$ at $4{ }^{\circ} \mathrm{C}$. After this last centrifugation step, the supernatants containing the MT were again separated and the samples were frozen at $-20^{\circ} \mathrm{C}$ until further analyses.

MT quantification was performed using a spectrophotometric method applying Ellman's reaction (Ellman, 1959), in which the purified samples were mixed with a $\mathrm{HCl} 1 \mathrm{~mol} \mathrm{~L}^{-1}$ and EDTA $4 \mathrm{mmol} \mathrm{L}^{-1}$ solution. Immediately afterwards, $\mathrm{NaCl} 2 \mathrm{~mol} \mathrm{~L}^{-1}$ containing $0.43 \mathrm{mmol} \mathrm{L}^{-1}$ 5,5-dithiobis (2-nitrobenzoic acid) buffered with $0.2 \mathrm{~mol} \mathrm{~L}^{-1}$ sodium phosphate, $\mathrm{pH} 8.0$ were added to the samples. These were then incubated in the dark for $30 \mathrm{~min}$ and their absorbances were measured in quartz microcuvettes at $412 \mathrm{~nm}$ on a UV-vis spectrophotometer (Lambda 35, Perkin Elmer).

MT concentrations were estimated using an analytical curve plotted using GSH as an external standard assuming a ratio of $1 \mathrm{~mol} \mathrm{MT}=20 \mathrm{~mol} \mathrm{GSH}$, as described previously (Mackay et al., 1993).

\subsection{Statistical analyses}

Data normality (metal, metalloids, MT and GSH data in muscle and digestive glands of $P$. perna mussels) was tested using the $W$ Shapiro-Wilkes test. As the data were non-parametric, they were normalized to the mean length of the mussels from each location. Thus, all statistical tests from this stage were conducted on parametric data. The ANOVA test was used to verify significant differences between the analyzed metal concentrations, MT and GSH levels in different mussel tissues and between different sampling sites. Pearson's correlation test was used to verify the existence of significant correlations between metal and metalloid concentration and MT and GSH data. The differences and correlations were considered significant at $p<0.05$. To assess the differentiation among the analyzed tissues and sampling sites based on the metal accumulation and to identify any statistical similarity among data due to overlapping of statistical ellipses, the data were also analyzed by means of a Discriminant Canonical Analysis. Data for this analysis were transformed to $(x+1)$. The metal, metallothionein and GSH concentrations were used as the input variables. This multivariate dependence technique is applied when establishing relationships between a non-metric dependent variable and metric independent variables. After defining the groups (tissues and season), the individual data elements (metals, MT and GSH) of each group were plotted in the reduced multivariate space, in which the new axes (functions 1, 2, and 3) explain a proportion of the total variability in the data. Only functions presenting $p<0.05$, variance above or close to $10 \%$ and/or eigenvalues above 1 were considered statistically significant. Group centroids were plotted using the canonical discriminant functions evaluated at group means, and each circle indicates the 95\% confidence ellipses. The standardized discriminant function coefficients are a measure of the association between the variables and the axes. The correlation between the position of each group relative to the standardized discriminant function coefficients determines the parameters responsible for its separation. Statistical analyses were performed using Statistica 10 (StatSoft) for Windows and graphs were plotted using both Statistica 10 and the Prism $5^{\circledR}$ software package.

\section{Results and discussion}

\subsection{Biometric data}

Table 1 displays the biometric data (shell length, width and height, as means \pm standard deviation) of the mussel pools per season and sampling site. Statistically significant differences were observed for length between the sampling sites, where IG mussel lengths were significantly higher than all three GB beaches. Thus, data were normalized to the mean length of the mussels from each location, in order to remove size effects (Lavradas et al., 2014).

Table 1

Biometric data (displayed as means \pm standard deviation) of the mussel pools per season and sampling site.

\begin{tabular}{llll}
\hline Summer & Length $(\mathrm{mm})$ & Width $(\mathrm{mm})$ & Height $(\mathrm{mm})$ \\
\hline IG & $70.3 \pm 4.3$ & $28.5 \pm 1.8$ & $26.3 \pm 1.6$ \\
DB & $49.3 \pm 8.9$ & $21.9 \pm 2.9$ & $18.3 \pm 2.1$ \\
UB & $37.8 \pm 4.1$ & $22.0 \pm 2.3$ & $15.4 \pm 2.3$ \\
VB & $49.9 \pm 6.7$ & $24.3 \pm 2.2$ & $17.4 \pm 2.0$ \\
& & & \\
Winter & Length (mm) & Width (mm) & Height (mm) \\
IG & $63.5 \pm 2.5$ & $24.1 \pm 0.7$ & $23.2 \pm 0.8$ \\
DB & $49.9 \pm 3.0$ & $23.3 \pm 0.8$ & $19.3 \pm 1.4$ \\
UB & $54.8 \pm 2.9$ & $29.0 \pm 1.4$ & $20.1 \pm 1.4$ \\
VB & $35.6 \pm 1.8$ & $16.4 \pm 0.3$ & $13.8 \pm 0.7$ \\
\hline
\end{tabular}

\subsection{Metal and metalloid concentrations}

Data for total metal and metalloid concentrations are displayed in Table 2. Most of the determined metals and metalloids were significantly higher $(p<0.05)$ in the digestive gland, with the exception of $\mathrm{Ni}$ and $\mathrm{Zn}$, which were higher in muscle tissue. This is in accordance with other studies conducted with different bivalves, since the digestive gland is known as the main accumulation target of several metal and metalloids due to its high metabolic activities and central role in detoxifying these contaminants from the body. However, different storage and detoxification mechanisms in different tissues/organs exist, which may justify the higher $\mathrm{Zn}$ and Ni concentrations in muscle tissue (Jebali et al., 2014). Another possibility is that chronic exposure to these elements was simply too much for the glands to cope with and remove from the body, resulting in accumulation in muscle tissue. Table 2 also shows that the means for all total GB samplings (summer and winter) were significantly different $(p<0.05)$ from the IG data: in muscle tissue, $\mathrm{Cu}$ concentrations were higher at UB and VB, while $\mathrm{Zn}$ and $\mathrm{Pb}$ levels were higher at $\mathrm{UB}, \mathrm{VB}$ and $\mathrm{DB}$ when compared to IG. As concentrations, on the other hand, were lower at UB and $\mathrm{Cd}$ levels were lower at DB and UB when compared to IG; in the digestive gland all elements were significantly different between the GB and IG sampling sites: At DB, UB and VB $\mathrm{Zn}, \mathrm{Cu}$ and $\mathrm{Pb}$ concentrations where significantly higher than IG levels, and As concentrations were significantly higher at DB when compared to IG. On the other hand, As, Ni and Se concentrations at UB and Cd concentrations at UB and VB were significantly lower when compared to IG. Cd concentrations were higher at IG. This was not expected, since IG has been considered a reference background area in previous studies (Francioni et al., 2004; Lima et al., 1986), and can be explained by the fact that sediments from Ilha Grande Bay are known to contain high $\mathrm{Cd}$ concentrations due to the influence of sulfide anomalies from the adjacent Serra do Mar mountain chain geology (Gomes et al., 2009; Lacerda et al., 1989).

Mussel farming is an important economic activity in Brazil, and 
Table 2

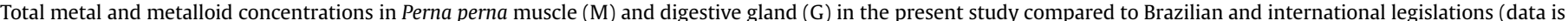
expressed as means \pm expanded uncertainty of the means (95\%), $\mu \mathrm{g} \mathrm{g}^{-1}$ wet weight).

\begin{tabular}{|c|c|c|c|c|c|c|c|c|}
\hline Area & Tissue/organ & $\mathbf{N i}$ & $\mathbf{C u}$ & $\mathbf{Z n}$ & As & Se & Cd & $\mathbf{P b}$ \\
\hline \multirow[t]{2}{*}{ IG } & $\mathbf{M}$ & $2.35 \pm 0.43$ & $0.78 \pm 0.09$ & $32.17 \pm 5.12^{*}$ & $3.90 \pm 0.19^{*}$ & $1.02 \pm 0.12^{*}$ & $0.167 \pm 0.022$ & $0.03 \pm 0.01$ \\
\hline & G & $1.43 \pm 0.09$ & $2.63 \pm 0.12$ & $15.47 \pm 0.68$ & $8.78 \pm 0.25$ & $1.86 \pm 0.06$ & $1.072 \pm 0.267^{*}$ & $0.08 \pm 0.01$ \\
\hline \multirow[t]{2}{*}{ DB } & $\mathbf{M}$ & $2.57 \pm 0.34$ & $1.04 \pm 0.09$ & $48.21 \pm 2.17$ & $4.24 \pm 0.22$ & $0.86 \pm 0.06$ & $0.090 \pm 0.006$ & $0.10 \pm 0.02$ \\
\hline & G & $1.34 \pm 0.12$ & $3.69 \pm 0.28$ & $21.39 \pm 0.84$ & $11.98 \pm 0.62$ & $1.68 \pm 0.16$ & $0.428 \pm 0.084$ & $0.29 \pm 0.04$ \\
\hline \multirow[t]{2}{*}{ YB } & $\mathbf{M}$ & $2.30 \pm 0.19$ & $1.98 \pm 0.19$ & $68.42 \pm 5.09$ & $2.75 \pm 0.16$ & $0.79 \pm 0.03^{*}$ & $0.036 \pm 0.003$ & $0.28 \pm 0.06$ \\
\hline & G & $0.95 \pm 0.06$ & $5.33 \pm 0.50$ & $22.87 \pm 0.90$ & $4.81 \pm 0.19$ & $1.40 \pm 0.06$ & $0.087 \pm 0.009$ & $0.60 \pm 0.10$ \\
\hline \multirow[t]{2}{*}{ VB } & $\mathbf{M}$ & $3.94 \pm 0.81^{*}$ & $1.58 \pm 0.19$ & $70.64 \pm 10.51^{*}$ & $4.50 \pm 0.31$ & $1.15 \pm 0.12$ & $0.115 \pm 0.006$ & $1.19 \pm 0.24$ \\
\hline & G & $1.61 \pm 0.19$ & $6.34 \pm 0.71$ & $30.27 \pm 3.63^{*}$ & $10.01 \pm 0.43^{*}$ & $1.88 \pm 0.16^{*}$ & $0.299 \pm 0.034$ & $1.71 \pm 0.32$ \\
\hline ANVISA & - & 5.0 & 30.0 & 50.0 & 1.0 & 0.3 & 1.0 & 2.0 \\
\hline FAO/WHO & - & - & 30.0 & 50.0 & - & - & 1.0 & 2.0 \\
\hline EPA & - & - & 20.0 & 30.0 & - & - & 2.0 & 0.8 \\
\hline
\end{tabular}

${ }^{*}$ Indicates statistically significant differences $(p<0.05)$.

these organisms are consumed by a great part of the population in most of the coastal zones in the country. The mussel $P$. perna is one of the most commercially cultivated bivalves in Brazil (IBAMA, 2007), with a production in the order of $12.500 \mathrm{t}$ in the last decades, representing $19 \%$ of the total produced by the entire Brazilian mariculture (Galvão et al., 2015). This organism is considered an adequate sentinel species for environmental contamination, including metal exposure, since it is sessile and a filter-feeder (Burlando et al., 2006; Cheung et al., 2006; Gaitanaki et al., 2004; Hamer et al., 2008b). Besides the potential effects on the health of the mussels themselves, the studied metal and metalloids show potential toxic effects in humans when ingested over certain permissible limits. $\mathrm{Cd}$, for instance, may induce kidney dysfunction and reproductive damages, while $\mathrm{Pb}$ damages the nervous system, causes brain disorders, affects the intelligence quotient in children and causes cardiovascular disease in adults (Ikem and Egiebor, 2005). Cu, although an essential element, can generate reactive oxygen species in the organism, and excess or deficiency of this element may lead to severe health problems (Kozłowski et al., 2006).

Mussels are usually ingested whole, with no previous tissue separation. As the present study analyzed both muscle tissue and digestive glands, both matrices were separately compared to Brazilian and international guidelines, in order to observe potential health risks to human consumers. If concentrations in one of the organs were higher than the maximum permissible concentrations, the sampling site was then considered contaminated and a reason for concern, since, as stated previously, the animals are ingested whole. Table 2 compares the total mean concentrations for the investigated metals and metalloids in the present study and the maximum permissible limits recommended by Brazilian health regulatory agencies, the Environmental Protection Agency (USA EPA) and the Food and Agriculture Organization of the United Nations (FAO). The recommended levels from these regulatory agencies are given in $\mathrm{mg} \mathrm{g}^{-1}$ wet weight. Thus, in order to compare the data from the present study with these permissible limits, the conversion factor applied was of $70 \%$ moisture, as reported in the literature for a variety of species, including mussels (Gomes et al., 2009).

As and Se levels in both muscle tissue and the digestive glands from all study areas were above the maximum permitted concentrations recommended by the Brazilian legislation. $\mathrm{Zn}$ in muscle tissue from UB and VB were above the maximum permissible limits for all the guidelines, while this element in muscle from IG and DB and from digestive glands from VB were higher than that allowed by the EPA. Cd concentrations in the digestive gland from IG were above the limits established by ANVISA and FAO, while $\mathrm{Pb}$ concentrations at VB are above EPA-recommended levels. This indicates that these organisms are improper for human consumption (as well other animals that prey on these bivalves).

GB has been regarded as one of the most polluted coastal environments of the Brazilian coast, being identified as a hotspot area for metals (Linoa et al., 2016). Previous studies indicate that several metal concentrations in urban street sediments in highways around Guanabara Bay are very high and are, therefore, an important source of pollution to the receiving rivers and to Bay, with the most polluted sites located in the center of Rio de Janeiro, where the Guanabara samples of the present study were collected, since these areas experience intense traffic conditions and sewage overflows, causing metal pollution of the sediments (Pereira et al., 2007). Anticorrosive and primer paints for ships are also an important source of $\mathrm{Zn}$ to this environment (Baptista-Neto et al., 2005). In addition, metal contamination sources around the bay include the Duque de Caxias refinery, which has also doubled as a huge dumping ground for all sorts of discarded waste, which then becomes slurry and leaches to the bay, in unknown amounts; the $813 \mathrm{t} \mathrm{day}^{-1}$ of solid waste that reaches the bay which also results in further slurry production (Coelho, 2007); and the marine oil terminals, commercial ports and advanced fuel stations around the bay. Although IG has been considered a reference site and a biodiversity hotspot, with a number of protected areas, two oil terminals and a nuclear power plant are located in the area, besides a great number of marinas and dockyards and the Angra dos Reis harbor, which promote considerable anthropogenic impacts on the region and could be potential sources of several metals to the area (Pinheiro et al., 2004). Although low levels have been consistently reported, the results presented herein indicate that this area can no longer be considered a reference site for metal contamination.

Brazil has an average daily consumption of $25 \mathrm{~g}$ of fish and seafood per capita, corresponding to $173 \mathrm{~g}$ per week. However, in the metropolitan area of Rio de Janeiro, this consumption is duplicated to $355 \mathrm{~g}$ per week (BRASIL, 2009). Taking this into account and using an average body weight of $70 \mathrm{~kg}$, metal and metalloid ingestion was calculated for a weekly consumption of mussels per body weight. Results indicate that As and Se concentrations in both tissues from all sampling sites, $\mathrm{Zn}$ in muscle at UB and VB and $\mathrm{Cd}$ in the digestive glands from IG were higher than the maximum permissible limit for human ingestion stipulated by Brazilian law, indicating that mussels from both IG and GB are not adequate for human consumption.

Table 3 compares the total concentrations of the elements from the present study with concentrations found in other studies conducted in Brazil and around the world. Most elements observed in mussels from IG and GB were present in higher concentrations than elements observed in other areas in Brazil, such as Sergipe and São Paulo, as well as other countries. Unfortunately, not many reports are found regarding metals in this species, which 


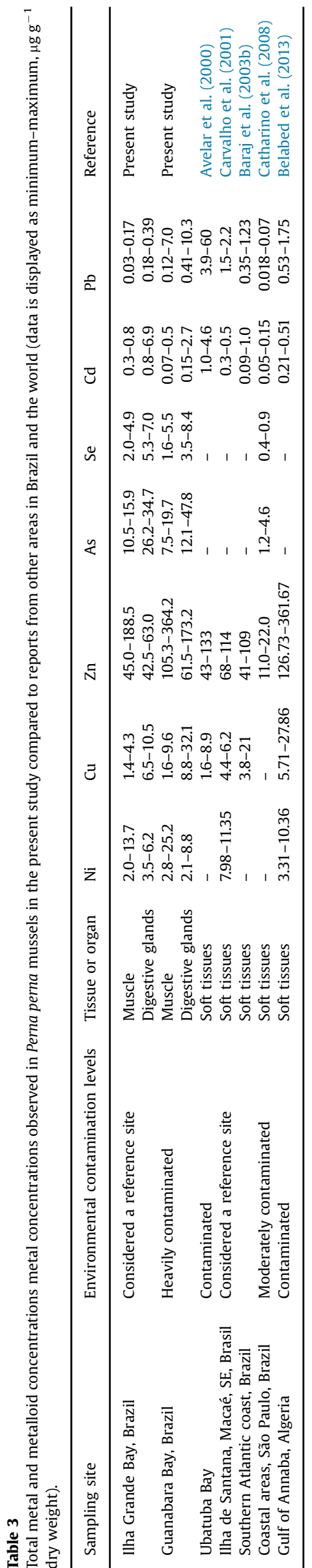

hampered discussion of the data. The table also displays the classification of each site regarding environmental metal levels. This indicates that GB is indeed an area heavily contaminated by these pollutants, and that IG cannot be considered a reference site any longer due to the presence of toxic metal levels.

\subsection{GSH and MT levels}

Total GSH and MT levels (both summer and winter) in the muscle tissue and digestive glands of the P. perna mussels analyzed in the present study are displayed in Fig. 1.

For GSH, no significant differences $(p>0.05)$ were observed for muscle and digestive glands at IG and UB, while at DB and VB this biomarker was significantly higher in digestive glands when compared to muscle tissue. Regarding muscle tissue, IG GSH concentrations were significantly higher than at $\mathrm{DB}$, while in the digestive glands higher concentrations at UB and VB were observed when compared to IG. Total GSH concentrations in muscle tissue were significantly and positively correlated to the following metals and metalloids: $\mathrm{Ni}, \mathrm{Cu}, \mathrm{Zn}, \mathrm{Se}, \mathrm{Cd}$ and $\mathrm{Pb}(\mathrm{IG}) ; \mathrm{Cu}(\mathrm{VB})$, and negatively correlated to $\mathrm{As}, \mathrm{Se}, \mathrm{Cd}$ and $\mathrm{Pb}(\mathrm{UB})$, while the following correlations were observed in digestive glands: $\mathrm{Cu}, \mathrm{Zn}$, Se and $\mathrm{Pb}$ (IG); Ni, Cu, Se and Pb (DB) (negative correlations), and Cd (IG, DB, UB and VB); As (DB and VB) (positive correlations). Correlations are very weak when $0.00<r<0.19$; weak when $0.20<r<0.39$; moderate when $0.40<r<0.69$; strong when $0.70<r<0.89$; and very strong when $0.90<r<1.00$ (Bryman and Cramer, 2011). All correlations observed between the analyzed parameters in the present study were either strong or very strong.

Reduced glutathione (GSH) is key in metal scavenging in the organism due to the high affinity of metals to its thiol (-SH) group (Jozefczak et al., 2012). GSH has been proposed to complex and detoxify metal cations as soon as they enter the cells, representing a first line of defense against metal cytotoxicity. According to the literature, metal accumulation in biological tissues can result in the reduction of the availability of GSH, although conflicting results have been reported, since studies conducted with mammals and fish show that the accumulation of certain metals such as $\mathrm{Cd}$, $\mathrm{Pb}$ and $\mathrm{Hg}$ resulted in increases in the availability of GSH. This has indicated that metals can in fact directly interfere in GSH metabolism (Canesi et al., 1999).

Regarding MT, concentrations were not significantly different between muscle tissue and digestive gland at the different sites, with the exception of IG, in which MT concentrations were significantly higher $(p<0.05)$ in muscle when compared to the digestive glands. MT concentrations in muscle tissue were significantly and negatively correlated to the following metals and metalloids: $\mathrm{Ni}, \mathrm{Cu}, \mathrm{Zn}$, As, Se, $\mathrm{Cd}$ and $\mathrm{Pb}$ (IG); Ni, $\mathrm{Cu}, \mathrm{Zn}$ and $\mathrm{Pb}(\mathrm{DB})$ and Se and $\mathrm{Cd}(\mathrm{VB})$, while the following correlations were observed in digestive glands: $\mathrm{Cu}, \mathrm{Zn}$, Se and $\mathrm{Pb}(\mathrm{IG}) ; \mathrm{Ni}, \mathrm{Cu}$, Se and $\mathrm{Pb}$ (DB); Se and $\mathrm{Pb}(\mathrm{VB})$ (negative correlations) and Cd (IG, DB, UB e $\mathrm{VB}$ ); $\mathrm{Ni}$ and $\mathrm{As}$ (IG) (positive correlations). All correlations observed between the analyzed parameters were either strong or very strong. These correlation data indicate that MT in this species can indeed be considered an adequate biomarker for metal exposure, as described previously, since it is important in the detoxification of non-essential metals, as well in essential element homeostasis (Mourgaud et al., 2002; Sakulsak, 2012). MT analysis in mussel digestive glands has been recommended by several international monitoring programs regarding environmental metal contamination (UNEP/RAMOGE, 1999).

This metalloprotein is usually present in higher amounts in the digestive gland when compared to other tissues and/or organs such as gills, since the digestive gland is the equivalent of the liver and is the main detoxifying organ of the body (Geret et al., 1998; Raspor et al., 1999; Simes et al., 2003). MT concentrations in 
A

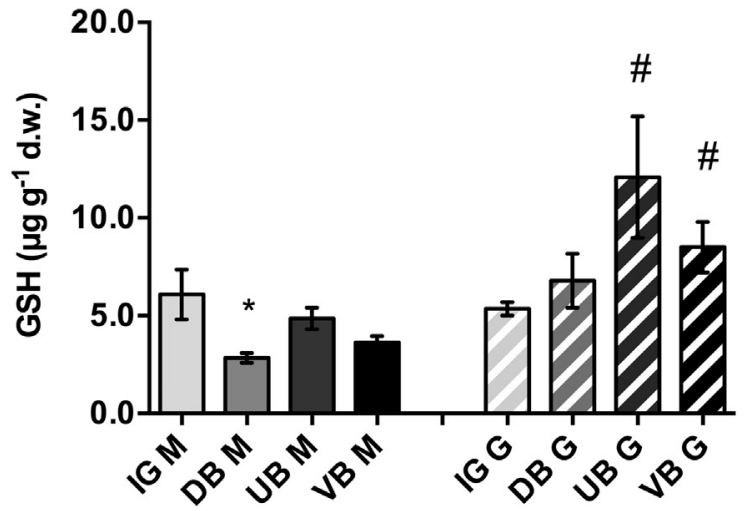

B

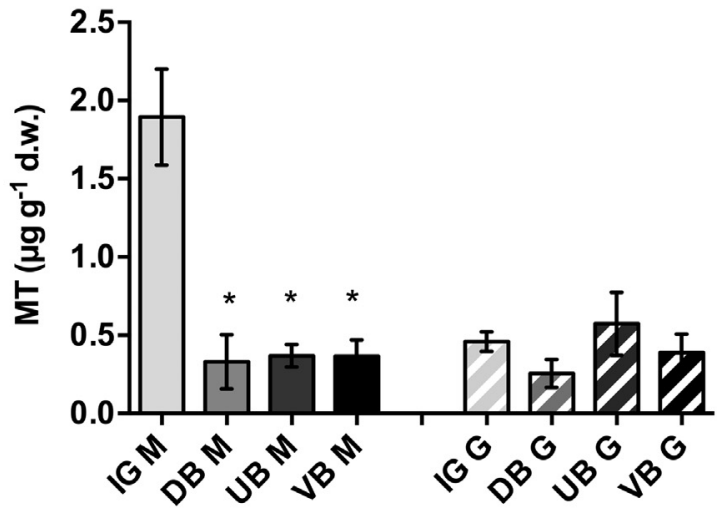

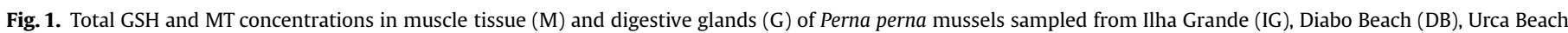

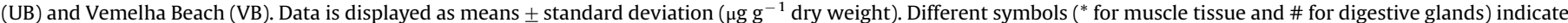
statistically significant differences compared to IG.

muscle tissue from IG were significantly $(p<0.05)$ higher than concentrations from GB in this same tissue. No significant differences were observed for this metalloprotein in the digestive glands from both sampling sites. MT synthesis in mussels can vary considerably between tissues (Zorita et al., 2007), and the most significant induction of this metalloprotein by metals was observed by $\mathrm{Cd}$ exposure both in field and laboratory experiments (Raspor et al., 1989). However, no records exist regarding MT synthesis in mussel muscle tissue, only in gills, mantle, digestive glands or soft tissue (Canesi et al., 1999; Geret and Cosson, 2002; Hardivillier et al., 2006; Mourgaud et al., 2002; Ramsak et al., 2012). As discussed above, Cd concentrations in IG muscle tissue were significantly higher than muscle tissue from GB, which may be the cause for the higher MT concentrations in mussels from this location. MT have also been reported as showing free radical scavenging abilities, but this protection mechanism has been postulated as being secondary, since certain studies have shown no direct relationship between oxidative stress and MT levels (Dondero et al., 2005). This corroborates with the results of the present study, since MT was only significantly correlated to GSH concentrations in the digestive gland at one sampling site in one season (VB, summer).

\subsection{Seasonality considerations}

\subsubsection{Metal and metalloid concentrations}

Metal concentrations for summer and winter are displayed in Table 4. Most elements were significantly higher in winter, with the exception of $\mathrm{Ni}$ in the digestive glands from IG, As at DB and VB (also in digestive gland) and $\mathrm{Cd}$ (digestive gland) from all sampling sites. This is in accordance to studies conducted by several authors (Giarratano and Amin, 2010; Hamed and Emara, 2006; Hamer et al., 2008b; Szefer et al., 2004) that also reported higher metal concentrations in mussels during winter. According to a recent study (Szefer et al., 2004), the higher precipitation that occurs in summer can be responsible for the dilution of pollutants and reduction in the concentration of metals in water and, consequently, in the organisms. These authors also report significant differences in the water temperature between summer and winter, which can affect mussel physiology and cause alterations in the metal concentrations present in these organisms. Comparisons were also conducted with regard to Brazilian and international guidelines separating data by season, and As and Se concentration in both summer and in winter were above the maximum permissible concentrations by both Brazilian and international guidelines, offering risks to human consumers, as discussed previously for total metal concentrations.

Table 4

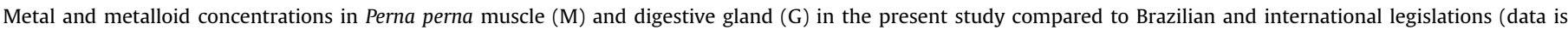
expressed as means \pm expanded uncertainty of the means (95\%), $\mu \mathrm{g} \mathrm{g}^{-1}$ wet weight) by season.

\begin{tabular}{|c|c|c|c|c|c|c|c|c|}
\hline Area & Tissue/organ & $\mathbf{N i}$ & $\mathbf{C u}$ & Zn & As & Se & Cd & $\mathbf{P b}$ \\
\hline \multirow[t]{2}{*}{ IG sum } & $\mathbf{M}$ & $1.1 \pm 0.2$ & $0.54 \pm 0.04$ & $15.8 \pm 1.1$ & $3.4 \pm 0.1^{*}$ & $0.64 \pm 0.01$ & $0.10 \pm 0.01$ & $0.012 \pm 0.001$ \\
\hline & G & $1.68 \pm 0.04$ & $2.3 \pm 0.1$ & $13.6 \pm 0.3$ & $9.2 \pm 0.3$ & $1.70 \pm 0.03$ & $1.9 \pm 0.1$ & $0.065 \pm 0.003$ \\
\hline \multirow[t]{2}{*}{ IG win } & $\mathbf{M}$ & $3.6 \pm 0.2$ & $1.0 \pm 0.1$ & $44.4 \pm 2.5$ & $4.4 \pm 0.1$ & $1.39 \pm 0.02$ & $0.2 \overline{2} \pm 0.01$ & $0.047 \pm 0.002$ \\
\hline & G & $1.18 \pm 0.03$ & $3.00 \pm 0.05$ & $17.3 \pm 0.3$ & $8.3 \pm 0.2$ & $2.01 \pm 0.02$ & $0.28 \pm 0.01$ & $0.101 \pm 0.004$ \\
\hline \multirow[t]{2}{*}{ DB sum } & $\mathbf{M}$ & $1.6 \pm 0.2$ & $0.8 \pm 0.1$ & $47.1 \pm 3.5$ & $4.4 \pm 0.3$ & $0.7 \pm 0.1$ & $0.08 \pm 0.01$ & $0.06 \pm 0.01$ \\
\hline & G & $1.1 \pm 0.2$ & $2.9 \pm 0.1$ & $22.5 \pm 0.9$ & $13.3 \pm 0.6$ & $1.21 \pm 0.04$ & $0.67 \pm 0.04$ & $0.17 \pm 0.02$ \\
\hline \multirow[t]{2}{*}{ DB win } & $\mathbf{M}$ & $3.5 \pm 0.1$ & $1.24 \pm 0.02$ & $49.1 \pm 1.1$ & $4.1 \pm 0.2$ & $1.0 \pm 0.1$ & $0.10 \pm 0.01$ & $0.140 \pm 0.002$ \\
\hline & G & $1.5 \pm 0.1$ & $4.5 \pm 0.1$ & $20.6 \pm 0.9$ & $10.7 \pm 0.3$ & $2.2 \pm 0.1$ & $0.19 \pm 0.01$ & $0.42 \pm 0.01$ \\
\hline \multirow[t]{2}{*}{ UB sum } & M & $2.1 \pm 0.2$ & $2.3 \pm 0.2$ & $68.9 \pm 5.8$ & $2.5 \pm 0.1$ & $0.76 \pm 0.03$ & $0.02 \overline{7} \pm 0.002$ & $0.14 \pm 0.01$ \\
\hline & G & $1.01 \pm 0.03$ & $4.2 \pm 0.1$ & $22.7 \pm 1.0$ & $5.0 \pm 0.2$ & $1.26 \pm 0.02$ & $0.11 \pm 0.01$ & $0.8 \pm 0.1$ \\
\hline \multirow[t]{2}{*}{ UB win } & $\mathbf{M}$ & $2.5 \pm 0.2$ & $1.7 \pm 0.2$ & $67.9 \pm 5.1$ & $3.0 \pm 0.2$ & $0.8 \pm 0.1$ & $0.044 \pm 0.003$ & $0.45 \pm 0.05$ \\
\hline & G & $0.9 \pm 0.1$ & $5.9 \pm 0.6$ & $23.1 \pm 0.9$ & $4.6 \pm 0.2$ & $1.5 \pm 0.1$ & $0.059 \pm 0.003$ & $0.45 \pm 0.02$ \\
\hline \multirow[t]{2}{*}{ VB sum } & $\mathbf{M}$ & $1.6 \pm 0.2$ & $1.0 \pm 0.1$ & $40.0 \pm 3.6$ & $3.7 \pm 0.2$ & $0.7 \overline{6} \pm 0.04$ & $0.098 \pm 0.001$ & $0.42 \pm 0.05$ \\
\hline & G & $1.14 \pm 0.05$ & $4.3 \pm 0.4$ & $22.4 \pm 1.2$ & $11.1 \pm 0.3$ & $1.4 \pm 0.1$ & $0.37 \pm 0.03$ & $0.7 \pm 0.1$ \\
\hline \multirow[t]{2}{*}{ VB win } & $\mathbf{M}$ & $6.3 \pm 0.3$ & $2.0 \pm 0.1$ & $101.3 \pm 2.0$ & $5.3 \pm 0.1$ & $1.53 \pm 0.03$ & $0.125 \pm 0.002$ & $1.8 \pm 0.1$ \\
\hline & G & $2.1 \pm 0.1$ & $7.9 \pm 0.5$ & $48.7 \pm 5.5$ & $8.9 \pm 0.2$ & $2.4 \pm 0.1$ & $0.218 \pm 0.003$ & $2.4 \pm 0.2$ \\
\hline ANVISA & - & 5 & 30 & 50 & 1 & 0.3 & 1 & 2 \\
\hline FAO/WHO & - & - & 30 & 50 & - & - & 1 & 2 \\
\hline EPA & - & - & 20 & 30 & - & - & 2 & 0.8 \\
\hline
\end{tabular}

${ }^{*}$ Indicates statistically significant differences $(p<0.05)$. 


\subsubsection{GSH and MT levels}

Comparisons between GSH and MT concentrations by season are displayed in Fig. 2. Regarding GSH, with the exception of muscle tissue from IG, levels in mussel $P$. perna were significantly higher in summer, in accordance with the MT results, which were also higher in this season. In muscle tissue, GSH concentrations from DB and VB were not significantly different between seasons, were significantly higher in winter at IG and significantly higher in summer at UB. In the digestive glands, GSH levels from all four sampling sites were significantly higher in summer. No significant correlations were observed for GSH concentrations in either winter or summer for muscle tissue, while this parameter in the digestive glands showed significant correlations to $\mathrm{Cd}$ at $\mathrm{DB}$ in winter, and to As and $\mathrm{Cd}$ at $\mathrm{UB}$ and $\mathrm{Zn}$ at VB in the summer (all positive, either strong or very strong).

Regarding MT, when separating and comparing summer and winter MT concentrations, it can be observed that MT levels were significantly higher, both in muscle tissue and digestive glands, in summer at both IG and GB, except in muscle tissue at UB, that did not present statistically significant differences. This corroborates reports in the literature, such as the report by Viarengo and collaborators (Viarengo et al., 1997) that also observed higher MT concentration in the summer. In the present study, however, most metals and metalloids were present in significantly higher concentrations in winter. The exception, however, was $\mathrm{Cd}$ in the digestive glands, which was significantly higher in summer. As MT and $\mathrm{Cd}$ showed strong, positive, statistical correlations, it is possible that this metal greatly influenced MT synthesis, as described in other reports (Raspor et al., 1989). MT concentrations in winter in muscle tissue were significantly correlated to the following metals and metalloids: $\mathrm{Ni}$ (IG); $\mathrm{Ni}$ and $\mathrm{Cd}$ (DB) (positive correlations) and Cd (VB) (negative correlation), while no significant relationships were observed for this tissue in the summer. The following correlations were observed in winter in the digestive glands: As (DB) and Ni (VB) (positive correlations), while, again, no significant correlations were observed for this tissue in the summer and all correlations were either strong or very strong.

It is interesting to note that, when separating the data by season, correlations were also observed between MT and GSH in the digestive gland at VB (positive, very strong) in the summer. Mussel reproduction occurs throughout the year. There are, however, more pronounced reproductive periods (breeding peaks) corresponding to the months of April, May and June (autumn), September (spring) and January (summer), with the latter two being the most intense (Marques, 1997). This is of note, as previous reports indicate that reproductive efforts can generate reactive oxygen species as by-products in several species, such as in oocyte maturation in crayfish for example (Liñán-Cabello et al., 2004), since these efforts lead to increased metabolic activity, ROS production and, consequently, oxidative stress as a result of reduced energy available for antioxidant defenses (Petes et al., 2008). Also, induction of MT has been correlated to certain abiotic factors, such as hyperthermia, hyposmotic stress, temperature and dissolved oxygen (Gourgou et al., 2010; Hamer et al., 2008a; Jarque et al.,
A
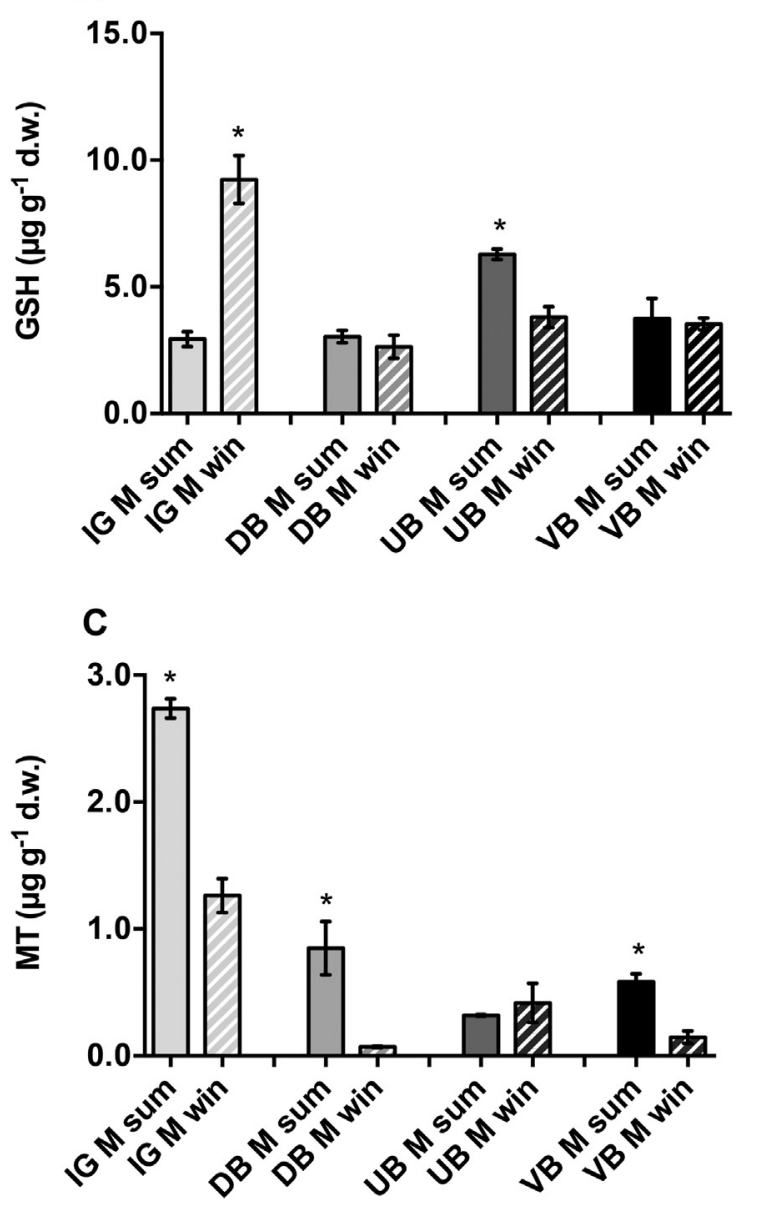

B

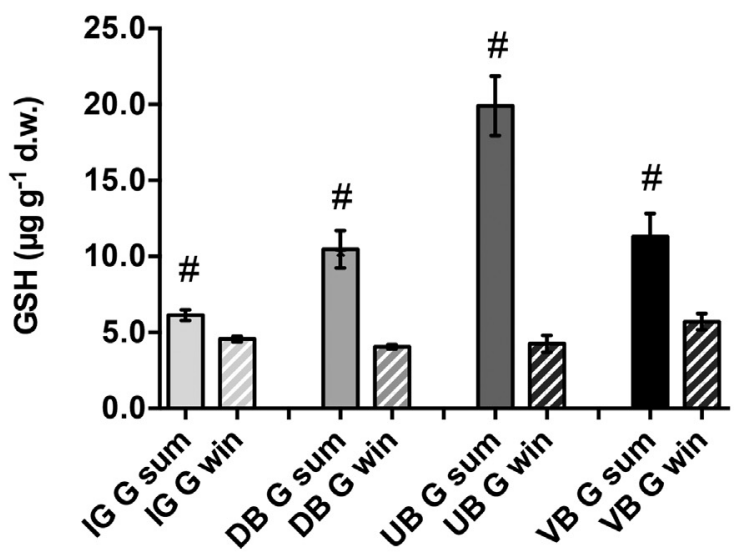

D

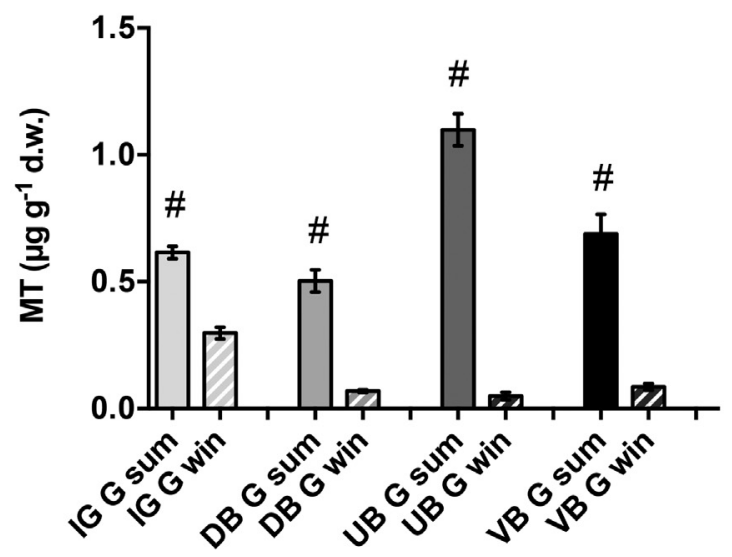

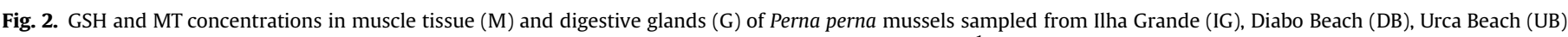

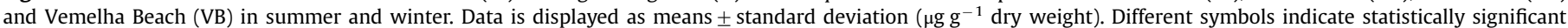
differences between the summer and winter groups for each location (* for muscle tissue and \# for digestive glands). 
2014). All these factors have been postulated as being the cause of seasonal variations in certain oxidative stress biomarkers (Petes et al., 2008), and might be the source of some of the variations observed in the present study with regard to MT, although the statistically significant correlations observed between these biochemical parameters and certain determined metals in both the digestive gland and muscle tissue point towards exposure to metals as an MT inductor in this case, especially since all correlations observed between MT and metals were either strong or very strong.

\subsubsection{Multivariate analyses}

Multivariate analyses were conducted in order to further investigate seasonality changes in the biochemical and metal parameters. Data were analyzed for muscle tissue and digestive gland separately. The results of the discriminant function analyses and the scatter plots of the functions are presented in Table 5 and Fig. 3, respectively.

When analyzing muscle data, 3 canonical functions, or factors, representing $94.8 \%$ of the total data variability were detected in the discriminant analyses. The first factor (Fig. 3A) represented

Table 5

Results of the discriminant function analysis on in P. perna muscle and digestive glands for summer and winter.

\begin{tabular}{|c|c|c|c|}
\hline \multicolumn{4}{|l|}{ Muscle } \\
\hline Discriminant function & 1 & 2 & 3 \\
\hline Eigen value & 23.66 & 19.87 & 8.07 \\
\hline Cum. proportion & 0.45 & 0.8 & 0.95 \\
\hline Variables & \multicolumn{3}{|c|}{ Standardized discriminant function coefficients } \\
\hline $\mathrm{Pb}$ & 1 & 0.09 & -0.23 \\
\hline $\mathrm{Cd}$ & 0.36 & -0.6 & 0.25 \\
\hline $\mathrm{Zn}$ & 0.44 & 1.25 & 0 \\
\hline As & -0.81 & -1.1 & -1 \\
\hline $\mathrm{Se}$ & 0.36 & 0.14 & 1.38 \\
\hline $\mathrm{Ni}$ & 0.42 & -0.62 & -0.57 \\
\hline MT & -0.49 & -0.38 & -0.32 \\
\hline $\mathrm{Cu}$ & -0.82 & 0.29 & 0.39 \\
\hline GSH & -0.32 & -0.09 & 0.5 \\
\hline \multicolumn{4}{|c|}{ Means of the canonical variables } \\
\hline IG sum & -4.1 & -2.69 & -2.38 \\
\hline DB sum & -3.31 & -1.74 & -2.47 \\
\hline UB sum & -2.08 & 6.97 & 2.42 \\
\hline VB sum & -0.7 & 0.78 & -1.55 \\
\hline IG win & -0.74 & -5.94 & 5.15 \\
\hline DB win & -0.14 & -1.45 & -0.77 \\
\hline UB win & 0.09 & 4.68 & 0.54 \\
\hline VB win & 10.99 & -0.62 & -0.94 \\
\hline \multicolumn{4}{|l|}{ Digestive glands } \\
\hline Discriminant function & 1 & 2 & 3 \\
\hline Eigen value & 101.01 & 51.73 & 28.44 \\
\hline Cum. proportion & 0.51 & 0.77 & 0.92 \\
\hline Variables & \multicolumn{3}{|c|}{ Standardized discriminant function coefficients } \\
\hline $\mathrm{Pb}$ & 0.09 & -0.83 & 0.6 \\
\hline $\mathrm{Cd}$ & 1.08 & -0.27 & -0.57 \\
\hline $\mathrm{Zn}$ & -0.51 & -0.07 & -0.74 \\
\hline As & -0.26 & 1.52 & 0.2 \\
\hline $\mathrm{Se}$ & -0.9 & -1.07 & -0.66 \\
\hline $\mathrm{Ni}$ & 0.47 & -0.66 & 0.86 \\
\hline MT & 0.97 & -1.14 & 1.24 \\
\hline $\mathrm{Cu}$ & 0.23 & -0.42 & 0.37 \\
\hline GSH & -0.06 & 0.37 & 0.1 \\
\hline \multicolumn{4}{|c|}{ Means of the canonical variables } \\
\hline IG sum & 18.87 & -4.77 & -5.78 \\
\hline DB sum & 3.73 & 12.05 & 0.48 \\
\hline UB sum & 4.11 & -5.2 & 9.51 \\
\hline VB sum & 1.91 & 4.56 & 4.65 \\
\hline IG win & -5.02 & 0.01 & -2.73 \\
\hline DB win & -8.7 & 2.79 & -2.83 \\
\hline UB win & -6.17 & -0.14 & -3.03 \\
\hline VB win & -8.73 & -9.31 & -0.26 \\
\hline
\end{tabular}

$41.54 \%$ of the total data variability, and was composed of $\mathrm{Pb}$, As and $\mathrm{Cu}$, that showed the highest coefficients $(1.00,-0.81$ and -0.82 , respectively) and contributed most to the discriminatory power of function 1. There was a slight correspondence of data from IG and DB in the summer only, and ellipses were overlapped. The second factor represented $35.20 \%$ of the total data variability, composed by $\mathrm{Zn}$, As and $\mathrm{Ni}$ (coefficients of $1.25,-1.10$ and -0.62 , respectively). Regarding data separated by the power of function 2 (Fig. 3B), there was a slight correspondence of data with some ellipses overlapped and better discrimination of data from IG in winter, and UB both in summer and in winter. Factor 3 was composed of As and Se, representing $14.2 \%$ of the total data variability.

When analyzing digestive gland data, 3 canonical functions were also detected in the discriminant analyses, representing $92 \%$ of the total data variability. The first factor represented $51.3 \%$ of the total data variability, and was composed of Cd, Se and MT, that presented the highest coefficients $(1.08,-0.81$ and -0.90 and 0.975 , respectively) and contributed most to the discriminatory power of function 1 . There was a slight correspondence of data from IG and UB in winter only, and ellipses were overlapped (Fig. 3C). Regarding the data separated by the power of function 2 (Fig. 3D) (26.3\% of the total data variability), the highest contributions were observed for As, Se, MT, Pb and Ni (coefficients of $1.522,-1.07,-1.14,-0.83$ and -0.66 , respectively). Again, there was a slight correspondence of data with some ellipses overlapped regarding data from IG and UB in the winter, but greater discrimination by sampling site and season when compared to muscle. Factor 3 was composed of $\mathrm{Se}, \mathrm{MT}, \mathrm{Pb}, \mathrm{Ni}$ e $\mathrm{Zn}$, representing $14.4 \%$ of the total data variability.

These results are further proof that the MT variations are due to metal concentrations, since GSH influence in the Discriminant Canonical Analysis for both muscle and digestive gland was nonsignificant $(p>0.05)$ and thus, did not contribute to data discrimination, while MT showed high discriminatory contribution in Factor 1 in the digestive gland.

\section{Conclusions}

P. perna mussels from all analyzed sites are improper for human consumption due to metal contamination, both in summer and in winter, including at Ilha Grande Bay, which is of note, since this location has generally been considered a reference site. This is, to the best of our knowledge, one of the first reports on metal contamination in Ilha Grande Bay, as well as the first report on muscle tissue biochemical parameters in this species and correlations with metals and metalloids, since most studies are conducted in soft tissues in their entirety.

Correlations were observed between the investigated MT, GSH and metals and metalloids, both for total data and separated by season, were observed, indicating that $P$. perna mussels are indeed adequate sentinel species for metal contamination. Most metals and metalloids determined in the digestive glands were significantly higher than in $P$. perna muscle tissue. This, allied to significant correlations between observed, and the results of the multivariate analyses conducted in the present study indicate that the digestive gland is a better bioindicator for environmental contamination by metals and metalloids in this species and offer further proof that MT variations observed are due to metal exposure and not oxidative stress, since GSH influence for both muscle and digestive gland was non-significant. MT free radical scavenging abilities were also shown to be secondary since only one instance of a direct relationship between oxidative stress and MT levels was observed in the present study. 
A

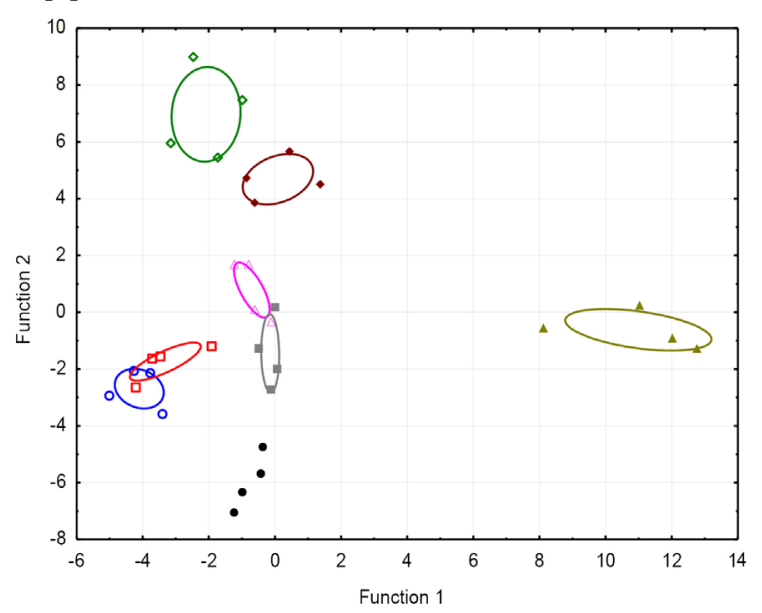

\section{C}

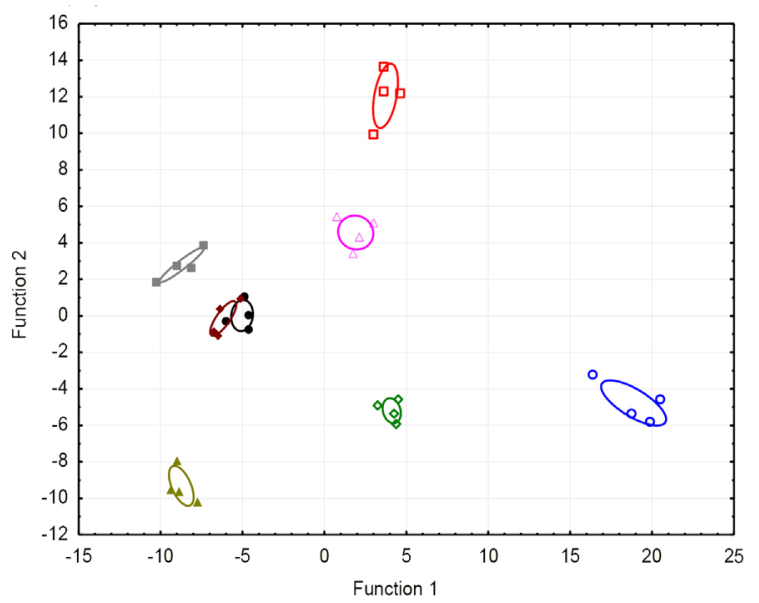

B
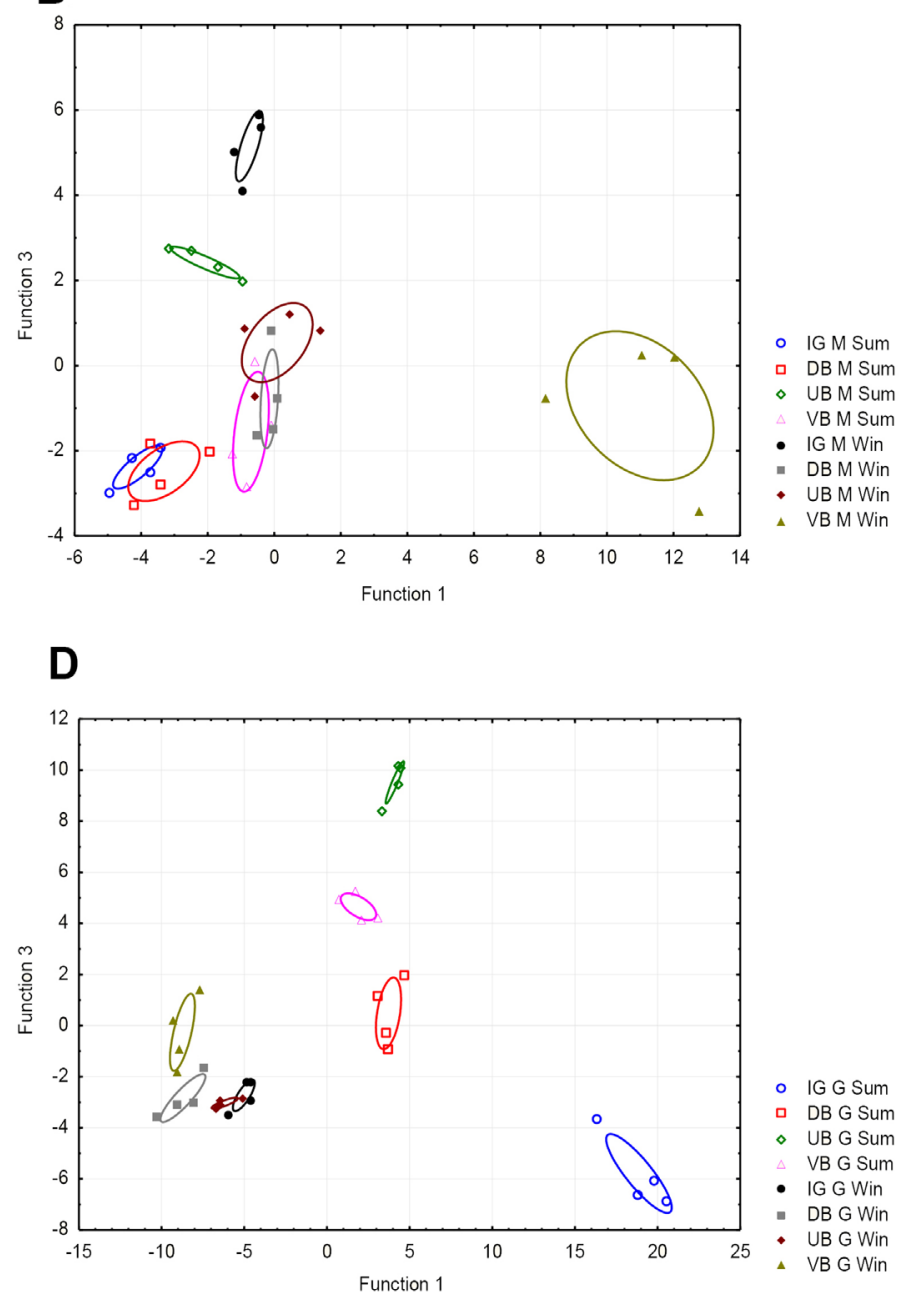

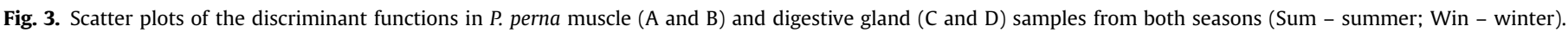

\section{Acknowledgments}

The authors would like to thank FAPERJ - Research Support Foundation of the State of Rio de Janeiro for the first author's doctorate scholarship.

\section{References}

Almeida, A.C.M., 2003. Geocronologia de compostos organicos de estanho e de alguns metais de relevância ambiental. Estudo de caso: Baía de Guanabara (Ph. D thesis). Departamento de Química,Pontifícia Universidade Católica do Rio de Janeiro, Rio de Janeiro, Vol..

Amador, E.S., 1997. Baía de Guanabara e ecossistemas periféricos: homem e natureza. Reproarte Gráfica e Editora Ltda.

Avelar, W.E.P., et al., 2000. The marine mussel Perna perna (Mollusca: Bivalvia, Mytilidae) as an indicator of contamination by heavy metals in the Ubatuba Bay, São Paulo, Brazil. Water Air Soil Pollut. 118, 65-72.

Baptista-Neto, J.A., et al., 2005. Concentration and bioavailability of heavy metals in sediments from Niterói Harbour (Guanabara Bay/S.E. Brazil). J. Coast. Res. 20 $0749-0208$

Baraj, B., et al., 2003a. Trace metal content trend of mussel Perna perna (Linnaeus, 1758) from the Atlantic Coast of Southern Brazil. Water Air Soil Pollut. 145, 205-214.

Baraj, B., et al., 2003b. Trace metal content trend of mussel Perna perna (Linnaeus, 1758) from the Atlantic coast of southern Brazil. Water Air Soil Pollut. 145, 205-214.

Belabed, B.E., et al., 2013. Factors contributing to heavy metal accumulation in sediments and in the intertidal mussel Perna perna in the Gulf of Annaba (Algeria). Mar. Pollut. Bull. 74, 477-489.

Beutler, E., 1975. Red Cell Metabolism: A Manual of Biochemical Methods. Grune and Stratton, New York.
Bizerril, C.R.S.F., Costa, P.A.S., 2001. Peixes marinhos do Estado do Rio de Janeiro. BRASIL, 2009. Boletim Estatístico da Pesca e Aquicultura. Ministério da Pesca e Agricultura, http://www.mpa.gov.br.

Bryman, A., Cramer, D., 2011. Quantitative Data Analysis with IBM SPSS Statistics 17, 18 and 19: A Guide for Social Scientists. Psychology Press, Hove.

Burlando, B., et al., 2006. Effects of seawater pollutants on protein tyrosine phosphorylation in mussel tissues. Aquat. Toxicol. 78, S79-S85.

Canesi, L., et al., 1999. Heavy metals and glutathione metabolism in mussel tissues. Aquat. Toxicol. 46, 67-76.

Cardoso, A.G.A., et al., 2001. Metal distribution in sediments from the Ribeira Bay, Rio de Janeiro - Brazil. J. Braz. Chem. Soc. 12, 767-774.

Carvalho, C.E.V., et al., 2001. Distribuição de Metais Pesados em Mexilhões (Perna perna, L.) da Ilha de Santana, Macaé, Brasil. Ecotoxicol. Environ. Restor. 4, 1-5.

Catharino, M.G.M., et al., 2008. Biomonitoring of $\mathrm{Hg}, \mathrm{Cd}$, Pb and other elements in coastal regions of São Paulo State, Brazil, using the transplanted mussel Perna perna (Linnaeus, 1758). J. Radioanal. Nucl. Chem. 278, 547-551.

Cheung, V.V., et al., 2006. An evaluation of the relative sensitivity of two marine bivalve mollusc species using the Comet assay. Mar. Environ. Res. 62, S301-S305.

Creed, J., et al., 2007. Biodiversidade Marinha da Baía da Ilha Grande. Ministério do Meio Ambiente - MMA, Brasília, p. 416.

Coelho, V.M.B., 2007. Baia de Guanabara - Uma História de Agressão Ambiental. Rio de Janeiro: Casa da palavra, 278, https://searchworks.stanford.edu/view/ 7143172 .

Dondero, F., et al., 2005. Quantitative PCR analysis of two molluscan metallothionein genes unveils differential expression and regulation. Gene 345, $259-270$.

Ellman, G.L., 1959. Tissue sulfhydryl groups. Arch. Biochem. Biophys. 82, 70-77.

Erk, M., et al., 2002. Evaluation of different purification procedures for the electrochemical quantification of mussel metallothioneins. Talanta 57, 1211-1218.

Francioni, E., et al., 2004. Evaluation of Perna perna (Linné, 1758) as a tool to monitoring trace metals contamination in estuarine and coastal waters of Rio de Janeiro, Brazil. J. Braz. Chem. Soc. 15, 103-110.

Gaitanaki, C., et al., 2004. Various stressors rapidly activate the p38-MAPK signaling pathway in Mytilus galloprovincialis (Lam.). Mol. Cell. Biochem. 260, 119-127. 
Galvão, P., et al., 2015. Estimating the potential production of the brown mussel Perna perna (Linnaeus, 1758) reared in three tropical bays by different methods of condition indices. J. Mar. Biol. 2015, 1-11.

Garrigues, P., et al. 2002. The impacts cluster of the European Commission. In: I Workshop of Biological Effects of Environmental pollution in The Marine Coastal Ecosystems (BEEP). Universidade de Pau, Pau, pp. 165-178.

Geret, F., et al., 1998. Metal compartmentalization and metallothionein isoforms in mussels from the Mid-Atlantic Ridge; preliminary approach to the fluid-organism relationship. Cah. Biol. Mar. 39, 291-293.

Geret, F., Cosson, R.P., 2002. Induction of specific isoforms of metallothionein in mussel tissues after exposure to cadmium or mercury. Arch. Environ. Contam. Toxicol. 42, 36-42.

Getz, E.B., et al., 1999. A comparison between the sulfhydryl reductants tris(2carboxyethyl)phosphine and dithiothreitol for use in protein biochemistry. Anal. Biochem. 273, 73-80.

Giarratano, E., Amin, O.A., 2010. Heavy metals monitoring in the southernmost mussel farm of the world (Beagle Channel, Argentina). Ecotoxicol. Environ. Saf. 73, 1378-1384.

Gomes, F.C., et al., 2009. Metal concentrations, fluxes, inventoris and chronologies in sediments from Sepetiba and Ribeira Bays: a comparative study. Mar. Pollut. Bull. 59, 123-133.

Gourgou, E., et al., 2010. Hyperthermia-induced Hsp70 and MT20 transcriptional upregulation are mediated by p38-MAPK and JNKs in Mytilus galloprovincialis (Lamarck); a pro-survival response. J. Exp. Biol. 213, 347-357.

Hamed, M.A., Emara, A.M., 2006. Marine molluscs as biomonitors for heavy metal levels in the Gulf of Suez, Red Sea. J. Mar. Syst. 60, 220-234.

Hamer, B., et al., 2008a. Effect of hypoosmotic stress by low salinity acclimation of Mediterranean mussels Mytilus galloprovincialis on biological parameters used for pollution assessment. Aquat. Toxicol. 89, 137-151.

Hamer, B., et al., 2008b. Effect of hypoosmotic stress by low salinity acclimation of Mediterranean mussels Mytilus galloprovincialis on biological parameters used for pollution assessment. Aquat. Toxicol. 89, 137-151.

Hardivillier, Y., et al., 2006. Metal influence on metallothionein synthesis in the hydrothermal vent mussel Bathymodiolus thermophilus. Comp. Biochem. Physiol. C: Toxicol. Pharmacol. 143, 321-332.

IBAMA, 2007. Coordenação Geral de Autorização de Uso e Gestão da Fauna e Recursos Pesqueiros, pp. 113.

Ikem, A., Egiebor, N.O., 2005. Assesment of trace elements in canned fishes (mackerel, tuna, salmon, sardines and herrings) marketed in Georgia and Alabama (United States of America). J. Food Compos. Anal. 18, 771-787.

Jarque, S., et al., 2014. Seasonal variations of gene expression biomarkers in Mytilus galloprovincialis cultured populations: temperature, oxidative stress and reproductive cycle as major modulators. Sci. Total Environ. 499, 363-372.

Jebali, J., et al., 2014. Comparative study of the bioaccumulation and elimination of trace metals ( $\mathrm{Cd}, \mathrm{Pb}, \mathrm{Zn}, \mathrm{Mn}$ and $\mathrm{Fe}$ ) in the digestive gland, gills and muscle of bivalve Pinna nobilis during a field transplant experiment. J. Trace Elem. Med. Biol. 28, 212-217.

Jozefczak, M., et al., 2012. Glutathione is a key player in metal-induced oxidative stress defenses. Int. J. Mol. Sci. 13, 3145-3175.

Junior, R.G.D.L., et al., 2002. Evaluation of heavy metals in fish of the Sepetiba and Ilha Grande Bays, Rio de Janeiro, Brazil. Environ. Res. 89, 171-179.

Kehrig, H.A., et al., 1998. Mercury in a widely consumed fish Micropogonias furnieri (Demarest, 1823) from four main Brazilian estuaries. Sci. Total Environ. 213, 263-271.

Kjerfve, B., et al., 1997. Oceanographic characteristics of an impacted coastal bay: Baia de Guanabara, Rio de Janeiro, Brazil. Cont. Shelf Res. 17 1609- +.

Kozłowski, H., et al., 2006. Metallochemistry of Neurodegeneration: Biological, Chemical, and Genetic Aspects. Royal Society of Chemistry, Cambridge, UK.

Kumari, M.V.R., et al., 1998. Free radical scavenging actions of metallothionein isoforms I and II. Free Radic. Res. 29, 91-101.

Lacerda, L.D., et al., 1989. Trace metals geochemical associations in sediments of a non-contaminated estuary. Ciênc. Cult. 41, 301-304.

Lavradas, R.T., et al., 2014. Metal, metallothionein and glutathione levels in blue crab (Callinectes sp.) specimens from southeastern Brazil. Ecotoxicol. Environ. Saf. 107, 55-60.

Liñán-Cabello, M.A., et al., 2004. Effects of carotenoids and retinol in oocytes maturation of crayfish Cherax quadrucarinatus. Aquac. Res. 35, 905-911.

Lima, N.R.W., et al., 1986. Temporal and spatial variability in $\mathrm{Zn}, \mathrm{Cr}$, Cd and Fe concentrations in oyster tissues (Crassostrea brasiliana, Lamarck 1819) from Sepetiba bay, Brazil. Environ. Technol. Lett. 7, 453-460.

Linoa, A.S., et al., 2016. Metal bioaccumulation in consumed marine bivalves in Southeast Brazilian coast. J. Trace Elem. Med. Biol. 34, 50-55.
MacFarlane, G.R., Burchett, M.D., 2000. Cellular distribution of copper, lead and zinc in the grey mangrove, Avicennia marina (Forsk.) Vierh. Aquat. Bot. 68, 45-59.

Mackay, E.A., et al., 1993. Complete amino acid sequences of five dimeric and four monomeric forms of metallothionein from edible mussel Mytilus edulis. Eur. J. Biochem. 218, 183-194.

Marques, L.A., 1997. Criação comercial de mexilhões. Nobel.

Miller, G.G., et al., 2002. In vitro toxicity and interactions of environmental contaminants (Arochlor 1254 and mercury) and immunomodulatory agents (lipopolysaccharide and cortisol) on thymocytes from lake trout (Salvelinus namaycush). Fish Shellfish Immunol. 13, 11-26.

Monteiro, D.A., 2006. Efeitos do inseticida organofosforado Metil Paration (Folisuper $600 \mathrm{BR}^{\mathbb{B}}$ ) sobre biomarcadores do estresse oxidante no teleósteo de água doce matrinxã Brychon cephalus (GÜNTHER, 1869) e o papel da suplementação de selênio na dieta Ciências Fisiológicas. Vol. MSc. Universidade Federal de São Carlos, São Carlos.

Moore, M.N., et al., 2004. An integrated biomarker-based strategy for ecotoxicological evaluation of risk in environmental management. Mutat. Res. 552, $247-268$.

Mourgaud, Y., et al., 2002. Metallothionein concentration in the mussel Mytilus galloprovincialis as a biomarker of response to metal contamination: validation in the field. Biomarkers 7, 479-490.

Pereira, E., et al., 2007. The contribution of heavy metal pollution derived from highway runoff to Guanabara Bay sediments: Rio de Janeiro/Brazil. An. Acad. Bras. Ciênc. 79, 739-750.

Petes, L.E., et al., 2008. Intertidal mussels exhibit energetic trade-offs between reproduction and stress resistance. Ecol. Monogr. 78, 387-402.

Pinheiro, F.M., et al., 2004. Assessing the impacts of organotin compounds in Ilha Grande Bay, (Rio de Janeiro, Brazil): imposex and a multiple-source dispersion model. J. Coast. Res. 39, 1383-1388.

Ramos, G., et al., 2000. Radicais livres, antioxidantes e adaptabilidade animal. In: ElHani, A.A.P., Videira, A.A.P. (Eds.), O que é vida: para entender a biología do século XXI, pp. 209-231.

Ramsak, A., et al., 2012. Evaluation of metallothioneins in Blue Mussels (Mytilus galloprovincialis) as a biomarker of mercury and cadmium exposure in the slovenian waters (Gulf of Trieste): a long-term field study. Acta Adriat. 53, $71-86$.

Raspor, B., et al., 1989. Cadmium-Induced Proteins from Mytilus galloprovincialis polarographic characterization and study of their interaction with cadmium. Mar. Chem. 28, 199-214.

Raspor, B., et al., 1999. Assessment of metal exposure of marine edible mussels by means of biomarker. In: Klaassen, C. (Ed.), Metallothionein IV. Birkhauser, Basel, Switzerland, pp. 629-632.

Sakulsak, N., 2012. Metallothionein: an overview on its metal homeostatic regulation in mammals. Int. J. Morphol. 30, 1007-1012.

Simes, D.C., et al., 2003. Isolation and characterisation of metallothionein from the clam Ruditapes decussatus. Aquat. Toxicol. 63, 307-318.

Szefer, P., et al., 2004. Distribution and coassociations of trace elements in soft tissue and byssus of Mytilus galloprovincialis relative to the surrounding seawater and suspended matter of the southern part of the Korean Peninsula. Environ. Pollut. 129, 209-228.

Tenório-Daussat, C.L., et al., 2014. Evaluation and standardization of different purification procedures for fish bile and liver metallothionein quantification by spectrophotometry and SDS-PAGE analyses. Talanta 120, 491-497.

UNEP/RAMOGE, 1999. Manual on the biomarkers recommended for the MED POL biomonitoring programme. UNEP, Athens.

Van Der Oost, R., et al., 2003. Fish bioaccumulation and biomarkers in environmental risk assessment: a review. Environ. Toxicol. Pharmacol. 13, 57-149.

Viarengo, A., et al., 1997. A simple spectrophotometric method for metallothionein evaluation in marine organisms: an application to Mediterranean and Antarctic molluscs. Mar. Environ. Res. 44, 69-84.

Viarengo, A., et al., 1999. Role of metallothionein against oxidative stress in the mussel Mytilus galloprovincialis. Am. J. Physiol. 277, R1612-R1619.

Viarengo, A., et al., 2007. The use of biomarkers in biomonitoring: a 2-tier approach assessing the level of pollutant-induced stress syndrome in sentinel organisms. Comp. Biochem. Physiol. Part C: Toxicol. Pharmacol. 146, 281-300.

Wilhelm-Filho, D., et al., 2005. Effect of different oxygen tensions on weight gain, feed conversion and antioxidant status in piapara, Leporinus elongatus (Valenciennes, 1847). Aquaculture 244, 349-357.

Zorita, I., et al., 2007. Assessment of biological effestc of environmental pollution along the NW Mediterranean Sea using mussels as sentinel organisms. Environ. Pollut. 148, 236-250. 